\title{
Protein quality of cottontail rabbit forages following range- land disturbance
}

\author{
D.G. PEITZ, R.L. LOCHMILLER, D.M. LESLIE, JR., AND D.M. ENGLE
}

Authors are former graduate student, Department of Zoology, Oklahoma State University, Stillwater, Okla., 74078; professor, Department of Zoology, Oklahoma State University, Stillwater, Okla., 74078; unit leader, U. S. National Biological Service, Oklahoma Cooperative Fish and Wildlife Research Unit, Oklahoma State University, Stillwater, Okla., 74078; and professor, Department of Agronomy, Oklahoma State University, Stillwater, Okla., 74078.

\begin{abstract}
Seasonal changes in the botanical composition of diets and protein quality of forages consumed by cottontail rabbits (Sylvilagus floridanus) were monitored on disturbed and undisturbed upland hardwood forest-tallgrass prairies in central Oklahoma. Our primary objective was to evaluate the seasonal dynamics of levels of selected amino acid nutrients in forages required for maintenance, growth, or reproduction, and explore how these changes respond to habitat disturbance resulting from the use of herbicides and fire. Microhistological analyses of stomach digesta indicated that summer diets were dominated by Panicum oligosanthes Schultes, Croton spp., and Sporobolus asper (Michx.) Kunth; winter diets were dominated by Bromus spp., $P$. oligosanthes, and Antennaria spp. Differences in the botanical composition and quality of diets between disturbed and undisturbed habitats were of little biological significance. Changes in the concentration of essential amino acids due to plant maturity were minimal in both summer and winter. Estimated levels of nitrogen and essential amino acids in reconstructed diets (based on food habits) appeared to be low, especially for the sulfur-containing amino acids (methionine + cystine) in summer.
\end{abstract}

Key Words: Sylvilagus floridanus, amino acids, brush management, diet quality, habitat quality, herbicides, prescribed burning

Advances in the study of nutritional ecology of hares and jackrabbits have provided strong evidence that food availability and diet quality are primary factors regulating population abundance (Keith 1987, Sinclair et al. 1982). Availability of quality forage has been linked to alterations in the onset of breeding and fecundity in snowshoe hares (Lepus americanus) (Keith 1983, Vaughan and Keith 1981) and white-tailed jackrabbits ( $L$. townsendii) (Rogowitz 1992), and juvenile survival in several

\footnotetext{
We acknowledge with great appreciation the efforts of many graduate and undergraduate students from Oklahoma State University with the collection of rabbits over the years. We also acknowledge the cooperation and funding of this project by the National Science Foundation (grants BSR8657043 and IBN9318066), the Oklahoma Agricultural Experiment Station (S-2036), and the Oklahoma Cooperative Fish and Wildlife Research Unit (National Biological Survey, Oklahoma State University, Oklahoma Department of Wildlife Conservation, and Wildlife Management Institute, cooperating). Approved for publication by the director, Oklahoma Agricultural Experiment Station.

Reprint requests should be sent to RLL.

Manuscript accepted 3 Nov. 1996.
}

lagomorphs (Gibb 1977, Keith 1983, Pease et al. 1979). Although much of it is indirect, current evidence suggests that cottontail rabbit (Sylvilagus floridanus) populations also respond to changing nutritional conditions in their habitat. This is supported by observations that food habits (Turkowski 1975), home range size (Anderson and Pelton 1976, Janes 1959, Trent and Rongstad 1974), foraging effort (Allen 1984, Anderson and Pelton 1976, Chapman et al. 1982, Janes 1959, Trent and Rongstad 1974), breeding success (Bothma and Teer 1977, Chapman et al. 1977, Chapman et al. 1982, Pelton and Provost 1972, Trethewey and Verts 1971), and population density (King et al. 1991, Lochmiller et al. 1991) vary among habitat types. Despite these many observations, our understanding of the proximate nutritional factors regulating these life history events remains elusive for this lagomorph.

White (1978) proposed that protein, composed of amino acids, was the most limiting nutrient category for many wild herbivore populations. Dietary protein supplies amino acids that rabbits cannot synthesize (termed "essential"); therefore, the ability of dietary protein to supply a proper balance of these essential amino acids will largely determine the nutritional quality of that protein (Oser 1959). Assessments of protein quality in diets of several waterfowl (Krapu and Swanson 1975, Sedinger 1984, Thomas and Prevett 1980), upland gamebird (Peoples et al. 1994, Steen et al. 1988), songbird (Murphy and Pearcy 1993), and primate (Oftedal 1991) species suggest that essential amino acids may be scasonally deficient relative to physiological requircments for many wild herbivores. Diets of cottontail rabbits are characteristically high in monocots and low in digestibility and total nitrogen, indicating that essential amino acid limitations may frequently be encountered in the wild. As a result, Chapman et al. (1982) suggested that sulfur-containing amino acids may be important nutrients limiting cottontail populations.

Our previous research studies on the impact to wildlife of using combinations of herbicides and fire to control woody vegetation encroachment onto prairie sites in the Cross Timbers showed that such brush management practices resulted in the following: 1) improved nutritional quality of selected herbaceous and woody plant species (Boglc et al. 1989, Soper et al. 1993), 2) increased primary production of woody (Stritzke et al. 1991) and understory vegetation (Engle et al. 1991), 3) increased rabbit densities (Lochmiller et al. 1991), and 4) improved body condition of rabbits (Lochmiller et al. 1995). These observations led us to hypothesize that forages in early growth stages and diets from disturbed (brush management) habitats would provide higher lev- 
els of essential amino acids (higher protein quality) and more closely meet requirements of cottontail rabbits for growth and lactation than forages in late growth stages and diets from undisturbed habitats. We elucidated seasonal changes in the essential amino acid composition of forage proteins consumed by cottontail rabbits from temperate, upland hardwood forests-tallgrass prairie habitat in central Oklahoma. Temporal changes in protein quality due to plant maturity were monitored for preferred forages consumed by cottontail rabbits, and food habit analyses were used to reconstruct diets to provide an overall estimate of essential amino acid concentrations in seasonal diets of rabbits in this study.

\section{Methods}

\section{Study Area}

We examined changes in protein quality of forages in the diet of cottontail rabbits from 2 disparate habitat types, located approximately $11 \mathrm{~km}$ southwest of Stillwater, Oklahoma $\left(36^{\circ} 2^{\prime}\right.$ to $36^{\circ} 4^{\prime} \mathrm{N}, 97^{\circ} 9^{\prime}$ to $97^{\circ} 11^{\prime} \mathrm{W}$ ). Disturbed and undisturbed study areas were arranged in a randomized complete block design with 2 fenced 32.4-ha $(0.42 \times 0.83 \mathrm{~km})$ replications of each habitat type. The study area encompassed land originally composed of upland forest with interspersed tallgrass prairie (Ewing et al. 1984). The Cross Timbers vegetation type accounts for nearly 5 million ha of rangeland in Oklahoma, Kansas, and Texas. Undisturbed upland forest habitats were dominated by Quercus marilandica Muenchh., Q. stellata Wang., and Juniperus virginiana $\mathrm{L}$. in the overstory, and Cornus drummondii Meyer, Celtis spp., and Symphoricarpos orbiculatus Moench. in the woody understory. Herbaceous ground cover was dominated by Schizachyrium scoparius Michx., Sorghastrum nutans (L.) Nash, P. oligosanthes Schultes, and Ambrosia psilostachya DC. Vegetation on tallgrass prairies was dominated by $S$. scoparius followed by $S$. nutans, and Andropogon gerardii Vitman.

Disturbed habitats were maintained in an early seral community by removal of woody overstory vegetation with the herbicide Triclopyr (Dow Chemical Co., Midland, Mich.) applied aerially at $2.2 \mathrm{~kg} \mathrm{ha}^{-1}$ in June 1983 and by burning in the springs of 1985 , 1986, 1987, and 1990. Disturbed habitats were dominated by Ulmus americana L. and J. virginiana in the overstory, S. orbiculatus in the woody understory, and $P$. oligosanthes, Conyza canadensis (L.) Cronq., and a mix of annual forbs in the herbaceous ground layer (Engle et al. 1991, Stritzke et al. 1991). Annual production of grass, forbs, and browse on undisturbed habitats was $2 \%, 1 \%$, and $20 \%$, respectively, of that on disturbed habitats. Densities of cottontails were greater on disturbed than undisturbed habitat types (Lochmiller et al. 1991). All habitats were seasonally grazed by yearling cattle from early spring to early to mid-fall.

\section{Data Collection}

Key forages (arbitrarily determined to be all identifiable food items in the diet) in summer (July 1990) and winter (January 1991) diets of cottontail rabbits were identified through microhistological analysis of stomach digesta (Davitt and Nelson 1980). A total of 10 digesta samples was obtained seasonally from stomachs of animals harvested from each of the 2 habitat replications ( 5 animals per replicate). Cottontail rabbits were collected (shot- gun) at a distance of $>75 \mathrm{~m}$ from boundary fences to minimize the chance that individuals were inhabiting both habitat types. Previous mark-recapture studies indicated that cottontail rabbit movement between habitat types was negligible (Lochmiller et al. 1991). Digesta samples were individually dried to constant weight by lyophilization, ground to pass through a 20-mesh screen, and mixed and composited by habitat replicate $(0.5 \mathrm{~g}$ stomach digesta/rabbit/habitat replication). Composited digesta samples were used to identify key forages in the diet. Composites were bleached, soaked for 1 week in lactophenol blue, and rinsed with water. Six representative subsamples from each composite were mounted on microscope slides. All slides were permanently fixed in glycerin gel, covered with a cover slip, and sealed with fingernail polish.

Botanical composition of each composited digesta sample was determined by (1) randomly locating 25 microscope fields on each of 6 microscope slides, (2) identifying the center-most plant fragment in each field at 100x by comparing with plant reference slides, and (3) counting the number of square microns of coverage for each fragment (McMurry et al. 1993). Relative percent composition of each plant species in the diet was calculated by summing the total number of square microns of coverage per plant species and dividing by the total number of square microns counted per digesta composite.

Key forages identified in 1990-1991 digesta samples were hand-collected a year later from each habitat replication during early (early-June or late-December) and late (mid-August or midMarch) growth stages within each season (summer and winter, respectively). Early and late growth stages did not necessarily represent immature and mature phenological stages of plants, but merely represented the phenological stage available at the beginning and end of a season (summer, winter). Herbaceous vegetation was clipped to ground level; bark and leaves of woody material were collected at a height $(<30 \mathrm{~cm})$ accessible to cottontail rabbits. Juniper berries were collected from the ground because these were generally the only ones available to cottontail rabbits. Forage samples were comprised of a minimum of 15 plants per species collected randomly from each habitat replicate. Herbaceous forages collected during summer and winter were actively growing (green) when collected. Collected forages were sorted to remove dead material and foreign debris, frozen, lyophilized to constant mass, and ground through a 20-mesh screen. Lipids were extracted from ground forage by using a Soxhlet apparatus and diethyl ether as a solvent (Williams 1984).

Protein quality was assessed by measuring concentrations of individual essential amino acids in forage samples following fat extraction and acid hydrolysis in $6 \mathrm{~N} \mathrm{HCl}$ at $110^{\circ} \mathrm{C}$ for 24 hours. Iydrolysates were precolumn derivatized with phenylisothiocynate and separated on a PICO-TAG reverse-phase column as previously described by Peoples et al. (1994). Derivatized amino acids were detected spectrophotometrically and measured by comparing peak area of the sample against that of a standard solution of known concentration. Concentrations of 17 individual amino acids (11 of which are thought to be essential to cottontail rabbits) were determined in derivatized samples. Concentrations obtained for methionine and cystine were combined as were phenylalanine and tyrosine, because cystine and tyrosine spare their respective amino acid nutritionally (Lebas 1988). Tryptophan was not measured due to destruction by acid hydrolysis (Gehrke et al. 1985, Sarwar et al. 1983). $\Lambda$ casein reference 
protein (from bovine milk, no. C-0376, Sigma Chemical Co., St. Louis, Mo.) of known amino acid composition was hydrolyzed and analyzed with forage samples for determination of amino acid recovery efficiency. Sulfur-containing amino acid loss during acid hydrolysis averaged $25 \%$; therefore, methionine + cystine concentrations recovered were adjusted upward $25 \%$. Amino acid concentrations were recorded on a dry mass basis ( $\mathrm{mg} \mathrm{g}^{-1}$ dry mass).

Nonextracted forage samples were analyzed for nitrogen $(\mathrm{N})$ content with a Labconco Rapid Kjeldahl System (Labconco Corp., Kansas City, Mo.) (Williams 1984). Nonprotein N concentrations in forages were a measure of the difference between amino acid $N$ (chromatography) and the total $N$ (Kjeldahl analysis) pools. Nonprotein $\mathrm{N}$ was assumed to be all $\mathrm{N}$ not incorporated into one of the amino acids recovered and was made up of a diverse group of compounds (Holt and Sosulski 1981, Maynard et al. 1979, Oka and Sasaoka 1985, Singh and Jambunathan 1981). Unlike other measures of nonprotein N (Holt and Sosulski 1981), we did not include free amino acids (those amino acids not bound in protein) that were recovered during analysis.

\section{Diet Quality}

Protein quality of seasonal diets was reconstructed from food habits data. Concentrations of each essential amino acid in the diet from each habitat type was calculated as the sum of the products of the relative contribution of each identified forage item in the diet and its corresponding seasonal average (early, late) concentrations of different amino acids. Seventy-five percent of the diets contained between $2 \%$ and $19 \%$ unidentified plant material that could not be specifically factored into profiles of diet quality, therefore, diet profiles were calculated with identified forages equalling $100 \%$ of the diet.

Published nutrient requirements for maintenance, growth, and reproduction do not exist for the cottontail rabbit, but are available for domestic rabbits. Undoubtedly, nutrient requirements (amino acids) are not completely comparable for these two species. However, due to the similarity in muscle amino acid composition (the primary use of amino acids) and estimated total $\mathrm{N}$ requirements of the 2 species, it is possible to suggest those essential amino acids which might be limiting in seasonal diets of cottontail rabbits (Smith 1980, Zinn and Owens 1993). Consequently, we compared estimated dietary levels of amino acids of wild cottontail rabbits to amino acid requirements published for the domestic rabbit to derive a general idea of the nutritional adequacy of seasonal diets for cottontail rabbits.

The overall quality of a protein in the diet depends on how well it meets essential amino acid requirements of the individual animal. Many empirical techniques have been developed to evaluate the quality or biological value of dietary proteins based upon their essential amino acid composition. We modified the chemical score technique (Mitchell and Block 1946) to compare the most limiting essential amino acid in each diet against growth requirements instead of against whole egg protein. Chemical scores have been demonstrated to have an inverse relationship with the biological value of a protein source (Mitchell and Block 1946). Biological value of dietary protein was determined by using a modification of the techniques described by Oser (1959). Briefly, we first calculated an essential amino acid index by comparing the concentrations of essential amino acids in each dietary protein to rabbit growth requirements, instead of their respective amounts in a reference protein.

\section{Data Analyses}

Differences in nutrient concentrations (including amino acids) of key forages between early and late growth stages were tested by one-way analysis of variance (PROC ANOVA; SAS 1988) by season. Differences in nutrient concentrations within a season between habitat types were examined by one-way ANOVA for those forages occurring in diets of rabbits from both disturbed and undisturbed areas. A few species occurring in small amounts in the diet were difficult to locate on our study areas during sample collections; in these cases, samples from both early and late collections were composited by equal mass into 1 sample for nutrient analyses. Season and habitat type differences in overall quality of proteins in diets were evaluated qualitatively by comparing calculated biological value estimates and extent of essential amino acid deficiencies. All differences discussed are significant at the $P<0.05$ level unless otherwise noted.

\section{Results}

\section{Diet Selection}

Cottontail rabbit diets were dominated by $P$. oligosanthes, Croton spp., and Sporobolus asper (Michx.) Kunth in summer and $P$. oligosanthes, Bromus spp., and Antennaria spp. in winter (Table 1). Monocots comprised approximately $65 \%$ of the identified forages in diets in summer and $72 \%$ in winter. Monocots

Table 1. Diet composition (\%) of cottontail rabbits (Sylvilagus floridanus) from disturbed and undisturbed upland hardwood forest-tallgrass prairie habitats during summer and winter.

\begin{tabular}{|c|c|c|c|c|}
\hline \multirow[b]{2}{*}{ Species } & \multicolumn{2}{|c|}{ Summer } & \multicolumn{2}{|c|}{ Winter } \\
\hline & $\begin{array}{c}\text { Disturbed } \\
\text { habitat }\end{array}$ & $\begin{array}{c}\text { Undisturbed } \\
\text { habitat }\end{array}$ & $\begin{array}{c}\text { Disturbed } \\
\text { habitat }\end{array}$ & $\begin{array}{c}\text { Undisturbed } \\
\text { habitat }\end{array}$ \\
\hline $\begin{array}{l}\text { Monocots } \\
\text { Andropogon gerardii } \\
\text { Sporobolus asper } \\
\text { Panicum oligosanthes } \\
\text { Paspalum setaceum } \\
\text { Sorghastrum nutans } \\
\text { Poa spp. } \\
\text { Bromus spp. } \\
\text { Carex spp. }\end{array}$ & $\begin{array}{c}3.2 \\
16.0 \\
34.1 \\
5.3 \\
0 \\
0 \\
0 \\
0\end{array}$ & $\begin{array}{c}0 \\
0.7 \\
30.6 \\
0 \\
7.0 \\
0 \\
0 \\
0\end{array}$ & $\begin{array}{c}0 \\
0 \\
25.7 \\
0 \\
0 \\
2.0 \\
30.3 \\
5.1\end{array}$ & $\begin{array}{c}\%) \\
0 \\
38.5 \\
0 \\
0 \\
1.7 \\
7.2 \\
16.8\end{array}$ \\
\hline $\begin{array}{l}\text { Dicots } \\
\text { Cocculus carolinus } \\
\text { Croton spp. } \\
\text { Plantago spp. } \\
\text { Antennaria spp. }\end{array}$ & $\begin{array}{c}6.8 \\
21.7 \\
0 \\
0\end{array}$ & $\begin{array}{c}0 \\
19.5 \\
4.8 \\
0\end{array}$ & $\begin{array}{c}0 \\
0 \\
0 \\
11.8\end{array}$ & $\begin{array}{c}0 \\
0 \\
0 \\
15.2\end{array}$ \\
\hline $\begin{array}{l}\text { Woody } \\
\text { Juniperus virginiana } \\
\text { berry } \\
\text { leaf } \\
\text { bark } \\
\text { Rhus copallina bark }\end{array}$ & $\begin{array}{l}0 \\
0 \\
0 \\
0\end{array}$ & $\begin{array}{l}0 \\
0 \\
0 \\
0\end{array}$ & $\begin{array}{c}5.1 \\
1.2 \\
0 \\
0.3\end{array}$ & $\begin{array}{r}14.0 \\
0.9 \\
2.2 \\
1.0\end{array}$ \\
\hline Unknowns & 12.9 & 34.4 & 18.5 & 2.5 \\
\hline
\end{tabular}

made up $67 \%$ of the diet in disturbed habitats and $63 \%$ in undisturbed habitats in summer and in higher quantities from disturbed (78\%) than undisturbed (66\%) habitats in winter. Dicots (forbs) and woody browse (leaf, bark, berries) collectively comprised $32 \%$ of the annual diet. Woody plants were not found in summer diets of rabbits but contributed approximately $13 \%$ to winter diets. Dicots contributed a larger portion to diets consumed by 

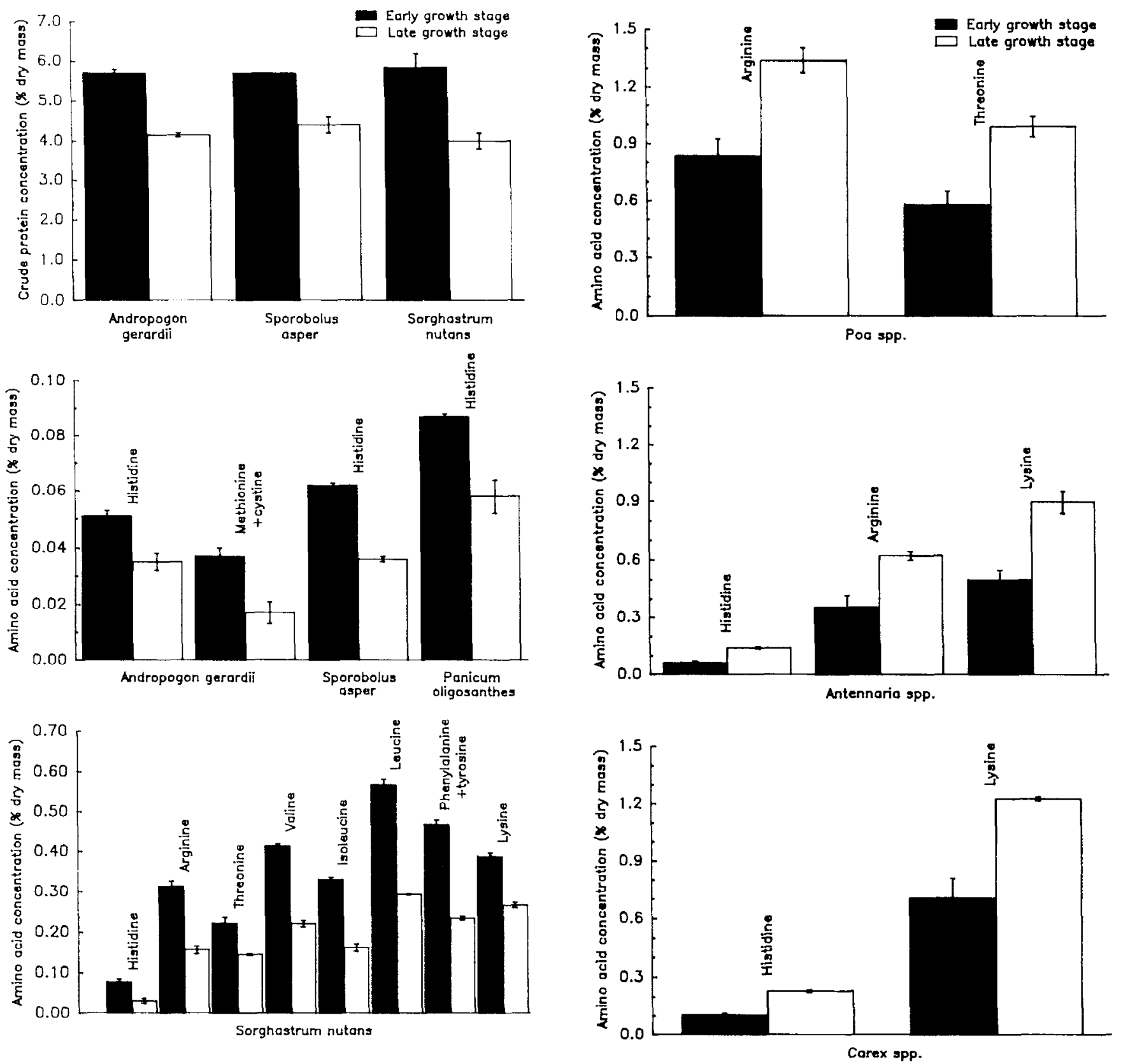

Fig. 1. Total $\mathrm{N}$ and essential amino acid contents (\% dry mass) of Andropogon gerardii from disturbed and Sporobolus asper and Sorghastrum nutans from undisturbed upland hardwood foresttallgrass prairie habitats by growth stage (early, late) in summer. Also shown is histidine content of Panicum oligosanthes from undisturbed habitats by growth stage in summer. All constituents shown varied significantly $(P<0.05)$ between early and late growth stage.

cottontail rabbits during summer $(35 \%)$ than winter $(15 \%$ of diet). Forages in diets from disturbed and undisturbed habitats differed to a greater degree in summer than in winter ( 5 of 8 forage species differed between diets in summer compared to 1 of 9 forage species differing between diets in winter).

Differences in concentrations of either total $N$, nonprotein $N$, or fat between early and late growth stages were observed in only 7 of 17 forages collected, indicating gross nutritional conditions

Fig. 2. Essential amino acid contents ( $\%$ dry mass) of Poa spp., Antennaria spp., and Carex spp. from undisturbed upland hardwood forest-tallgrass prairie habitats by growth stage (early, late) in winter. Lysine contents for Antennaria spp. are average values for samples collected from both disturbed and undisturbed habitats, as levels of this essential amino acid varied by growth stage on both habitat types. All constituents shown varied significantly $(P<0.05)$ between early and late growth stage.

remained largely unchanged within a season (Figs. 1 and 2, Table 2). No ubiquitous trends in nutrient composition of plant species were evident from our comparisons between early and late growth stages (overall means in Table 2). In general, alterations occurred more frequently on undisturbed than disturbed habitats. With summer maturity, concentrations of total $N$ decreased in $S$. nutans (32\% decline) and S. asper (23\% decline) on undisturbed habitats and A. gerardii ( $27 \%$ decline) on disturbed habitats (Fig. 
Table 2. Content (mean $\pm S E$ ) of fat, total $N(x 6.25)$, and nonprotein $N$ in selected forages in summer and winter diets of cottontail rabbits (Sylvilagus floridanus) from upland hardwood forest-tallgrass prairie habitat.

\begin{tabular}{|c|c|c|c|c|}
\hline Forage & $n$ & Fal & Total N & Nonprotein $\mathrm{N}$ \\
\hline 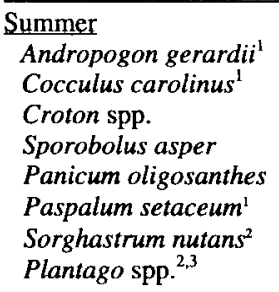 & $\begin{array}{l}4 \\
4 \\
8 \\
8 \\
8 \\
4 \\
4 \\
2\end{array}$ & $\begin{array}{l}(\% \text { DW }) \\
2.4 \pm 0.17 \\
2.1 \pm 0.23 \\
3.8 \pm 0.01 \\
1.9 \pm 0.14 \\
4.5 \pm 0.25 \\
2.2 \pm 0.16 \\
2.6 \pm 0.28 \\
3.6 \pm 0.45\end{array}$ & $\begin{array}{l}(\% \mathrm{DW}) \\
4.9 \pm 0.45^{*} \\
9.1 \pm 0.83 \\
9.1 \pm 0.49 \\
4.5 \pm 0.33^{\alpha} \\
6.8 \pm 0.35 \\
6.1 \pm 0.50 \\
4.9 \pm 0.56 \\
7.7 \pm 1.40\end{array}$ & $\begin{array}{c}(\% \text { of total } \mathrm{N}) \\
37.2 \pm 4.71 \\
40.7 \pm 0.20 \\
27.5 \pm 3.22 \\
35.5 \pm 1.75 \\
31.4 \pm 2.82^{\alpha} \\
44.7 \pm 1.06 \\
27.0 \pm 0.23 \\
31.4 \pm 0.47\end{array}$ \\
\hline \multicolumn{5}{|l|}{ Winter } \\
\hline $\begin{array}{l}\text { Poa spp. } \\
\text { Bromus spp. } \\
\text { Panicum oligosanthes } \\
\text { Antennaria spp } \\
\text { Carex spp. }\end{array}$ & $\begin{array}{l}8 \\
8 \\
8 \\
8 \\
8\end{array}$ & $\begin{array}{l}3.4 \pm 0.80 \\
3.4 \pm 0.24 \\
2.2 \pm 0.22^{\alpha} \\
2.4 \pm 0.34 \\
2.0 \pm 0.09 \alpha\end{array}$ & $\begin{array}{l}18.6 \pm 1.58 \\
19.3 \pm 1.24 \\
17.5 \pm 1.01 \\
10.6 \pm 0.67 \\
14.8 \pm 1.01\end{array}$ & $\begin{array}{c}25.4 \pm 3.05 \\
23.3 \pm 2.17 \\
34.1 \pm 1.67^{*} \\
32.3 \pm 3.72^{\alpha} \\
28.2 \pm 2.79\end{array}$ \\
\hline $\begin{array}{l}\text { Juniperus virginiana } \\
\text { berry }^{3} \\
\text { leaf }^{3} \\
\text { bark }^{2,3}\end{array}$ & $\begin{array}{l}4 \\
4 \\
2\end{array}$ & $\begin{array}{l}14.8 \pm 1.25 \\
10.0 \pm 0.60 \\
10.6 \pm 0.75\end{array}$ & $\begin{array}{l}5.9 \pm 0.34 \\
7.9 \pm 0.11 \\
4.7 \pm 1.05\end{array}$ & $\begin{array}{l}40.1 \pm 4.26 \\
33.4 \pm 2.22 \\
48.0 \pm 3.88\end{array}$ \\
\hline $\begin{array}{l}\text { Rhus copallina } \\
\text { bark }^{3}\end{array}$ & 4 & $8.8 \pm 0.59$ & $4.8 \pm 0.13$ & $29.9 \pm 2.43$ \\
\hline
\end{tabular}

${ }^{1}$ Collected from disturbed habitat only.

${ }^{2}$ Collected from undisturbed habitat only.

${ }^{3}$ Early and late growth stages were composited prior to analysis.

* Differed $(P<0.05)$ betwecn collection periods on disturbed habitat.

$\alpha_{\text {Differed }}(\mathrm{P}<0.05)$ between collection periods on undisturbed habitat.

1). Nonprotein $\mathrm{N}$ concentrations in $P$. oligosanthes from undisturbed habitats increased $36 \%$ with summer maturity, but levels declined $19 \%$ on disturbed habitats in winter. Concentrations of nonprotein $\mathrm{N}$ declined $24 \%$ in Antennaria spp. from undisturbed habitats in winter. Fat content of Carex spp. declined 13\% but increased $73 \%$ in $P$. oligosanthes with maturity during winter on undisturbed habitats.
During summer, most of the forages eaten by rabbits showed phenological changes in only $\leq 2$ essential amino acids, except $S$. nutans which varied considerably in composition (overall means in Table 3). Essential amino acid concentrations in $S$. nutans from undisturbed habitats declined an average of $48 \%$ with maturity (Fig. 1). Changes in summer occurred most frequently for histidine concentrations ( 4 of 8 species). Andropogon gerardii from disturbed habitats declined proportionately more in methionine + cystine $(55 \%)$ and histidine $(31 \%)$ contents than in total $\mathrm{N}$ content (Fig. 1). On undisturbed habitats histidine concentrations were observed to decline $42 \%$ in $S$. asper and $33 \%$ in $P$. oligosanthes during summer. Phenological changes in essential amino acid concentrations were not observed during summer for Cocculus carolinus (L.) DC., Croton spp., and Paspalum setaceum Michx. Of all essential amino acids in forages examined during summer, methionine + cystine, and to some degree histidine, were consistently present in the least quantity.

Concentrations of essential amino acids tended to remain stable or increase with forage maturity during winter as opposed to changes during summer (Table 4). Arginine (60\% increase) and threonine (70\% increase) concentrations increased in Poa spp. with increasing maturity on undisturbed habitats (Fig. 2). Histidine and lysine increased $124 \%$ and $62 \%$ in Antennaria spp., and $119 \%$ and $74 \%$, respectively, in Carex spp. with increasing maturity on undisturbed habitats during winter. Antennaria spp. on disturbed habitats had increases of $75 \%$ for arginine and $95 \%$ for lysine during the winter growing season. No differences in concentrations of essential amino acids were observed during winter for woody plant forages.

For the 10 forages occurring in diets of rabbits from both disturbed and undisturbed habitats, only 3 showed differences between habitats. During summer, arginine and phenylalanine + tyrosine contents in $S$. asper averaged $60 \%$ and $49 \%$ greater in undisturbed than disturbed habitats. Content of phenylalanine + tyrosine in Carex spp. was $46 \%$ greater, and content of histidine

Table 3. Content ( $\%$ dry mass) of amino acids in selected forages consumed by cottontail rabbits (Sylvilagus floridanus) in summer. Values represent mean \pm SE content for plant samples collected during early and late growth stages from 2 disturbed and 2 undisturbed upland hardwood forest-tallgrass prairie habitats.

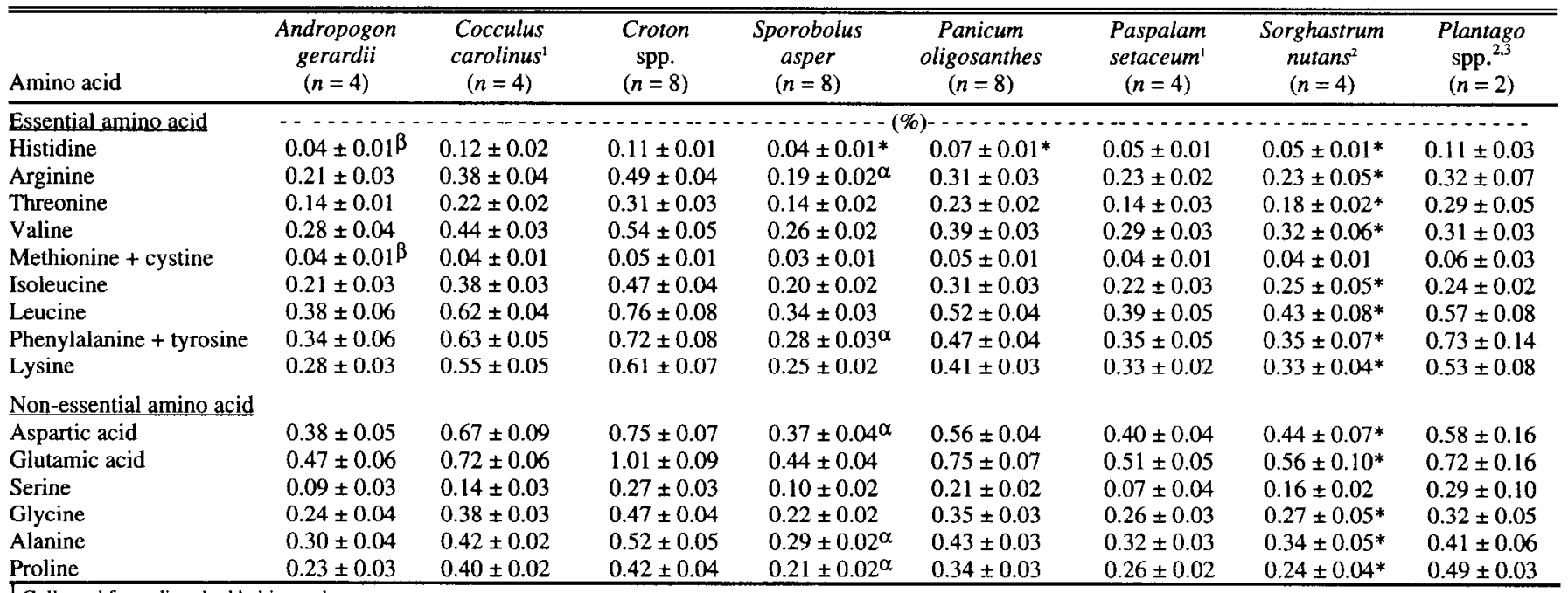

Collected from disturbed habitat only.

${ }^{2}$ Collected from undisturbed habitat only.

${ }^{3}$ Early and late growth stages were composited prior to analysis.

* Differed $(P<0.05)$ hetween collection periods on undisturbed habitat

${ }^{\alpha}$ Differed $(P<0.05)$ between disturbed and undisturbed habitat types.

${ }^{\circ}$ Differed $(\mathrm{P}<0.05)$ between collection periods on disturbed habitat. 
Table 4. Content (\% dry mass) of amino acids in selected forages consumed by cottontail rabbits (Sylvilagus floridanus) in winter. Values represent mean \pm SE content of plant samples collected during early and late growth stages from 2 disturbed and 2 undisturbed upland hardwood forest-tallgrass prairie habitats.

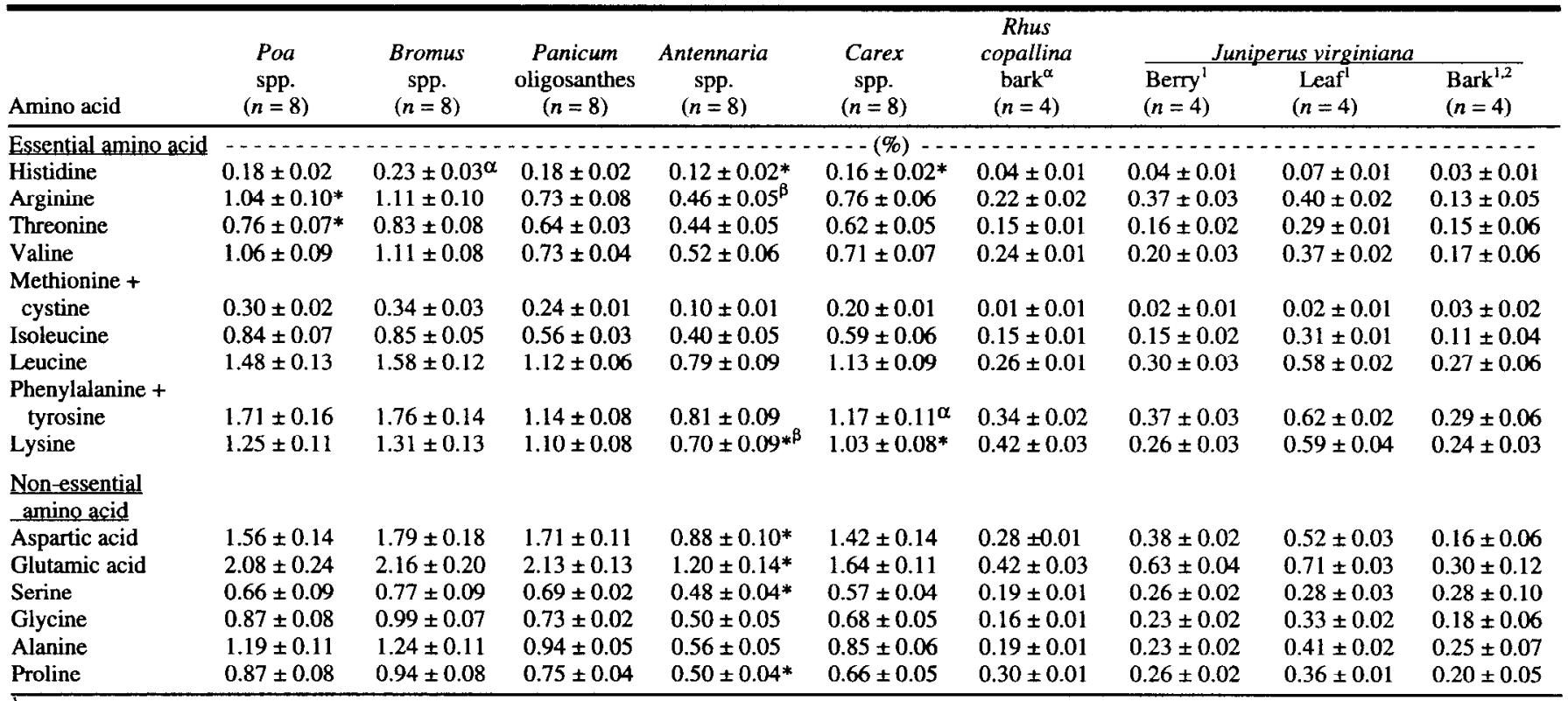

Early and late growth stages were composited prior to analysis.

${ }^{2}$ Collected from undisturbed habitat only.

* Differed $(P<0.05)$ between collection periods on undisturbed habitat.

${ }^{\alpha}$ Differed $(P<0.05)$ between disturbed and undisturbed habitat types.

Differed $(\mathrm{P}<0.05)$ between collection periods on disturbed habitat.

in Bromus spp. was $59 \%$ greater on disturbed than undisturbed habitats in winter (Table 4). Habitat disturbance had no influence on concentrations of total $\mathrm{N}$, nonprotein $\mathrm{N}$, and fat in any forage.

\section{Diet Composition and Quality}

Diets of cottontail rabbits from both disturbed and undisturbed habitats appeared to be limiting in some essential amino acids when compared to growth and lactation requirements published for domestic rabbits (Table 5). No essential amino acid met estimated requirements in summer, regardless of habitat type. Compared to growth and lactation requirements, apparent methionine + cystine deficiencies were as high as $92 \%$ in summer and $70 \%$ in winter, making sulfur-containing amino acids the most limiting group of amino acids in cottontail rabbit diets. Methionine + cystine deficiencies were suggested in both disturbed and undisturbed habitats during summer. In winter, plants in disturbed habitats appeared to provide $10 \%$ more of the dietary requirement for sulfur-containing amino acids than those in undisturbed habitats.

Histidine appeared to be the second most limiting amino acid, with dietary limitations for growth estimated at $33 \%$ and $77 \%$ in disturbed habitats and $53 \%$ and $70 \%$ in undisturbed habitats in winter and summer, respectively. Levels of all essential amino acids (except methionine + cystine) in the diet of rabbits from disturbed habitats were lower compared to those from undisturbed habitats in summer. Total $\mathrm{N}$ levels were $13 \%$ lower while essential amino acid contents averaged $16 \%$ lower on disturbed than undisturbed habitats in summer. The reverse was true for winter diets; diets of cottontails from disturbed habitats contained $23 \%$ more total $\mathrm{N}$ and averaged $36 \%$ higher levels of essential amino acids than those from undisturbed habitats.
Similar to individual forages, estimated nonprotein $\mathrm{N}$ content of cottontail rabbit diets was high, averaging $31 \%$ of the total $\mathrm{N}$ pool as determined by Kjeldahl analysis (Table 5). Calculated biological value of dietary proteins (based on essential amino acid composition) was $29 \%$ higher on undisturbed than disturbed habitats in summer. However, both calculated biological value and chemical score reflected extremely poor quality protein sources in the diets of rabbits from both habitats in summer. Diets of rabbits from disturbed habitats had biological values $43 \%$ higher than those from undisturbed habitats in winter. Biological value of winter diets was $163 \%$ higher than summer diets.

\section{Discussion}

Diets of cottontail rabbits were dominated by grasses in both summer and winter, with variable amounts of forbs, browse, and cedar berries. Botanical composition resembled previously reported diets for this species in other locations (Korschgen 1980). Use of browse and cedar berries by cottontail rabbits in winter suggested an inadequacy of herbaceous vegetation in meeting winter dietary requirements; browse and berries are generally eaten during periods of food stress and high energy demands (Korschgen 1980). The seasonal dietary shift from summer to winter was characterized by replacement of warm-season grasses with cool-season grasses in winter.

Within seasons, forage quality did not change appreciably, indicating that plants matured by early summer or remained in a dormant, immature state throughout winter. This suggested that diet quality of rabbits in upland hardwood forest-tallgrass prairie remains largely unchanged over much of the summer and winter. 
Table 5. Estimated nutritional quality ( $\%$ dry mass) of reconstructed diets consumed by cottontail rabbits (Sylvilagus floridanus) from upland hardwood forest-tallgrass prairie habitats, as influenced by habitat disturbance and season.

\begin{tabular}{|c|c|c|c|c|c|c|}
\hline & \multicolumn{2}{|c|}{ Summer } & \multicolumn{2}{|c|}{ Winter } & \multirow{2}{*}{\multicolumn{2}{|c|}{ ed_Requirements: }} \\
\hline & $\begin{array}{l}\text { Undisturbed } \\
\text { habitat }\end{array}$ & $\begin{array}{l}\text { Disturbed } \\
\text { habitat }\end{array}$ & $\begin{array}{c}\text { Undisturber } \\
\text { habitat }\end{array}$ & $\begin{array}{l}\text { Disturbed } \\
\text { habitat }\end{array}$ & & \\
\hline & $\cdots-\cdots$ & - & $-(\%$ & (n- & & \\
\hline $\begin{array}{l}\text { Total N (x 6.25) } \\
\text { Nonprotein N }\end{array}$ & 7.58 & 6.60 & 13.41 & 16.48 & 16.00 & 18.00 \\
\hline $\begin{array}{l}\text { Nonprotein N } \\
(\% \text { total } N)\end{array}$ & 28.93 & 34.45 & 34.68 & 27.80 & 0 & 0 \\
\hline Fat & 4.05 & 3.32 & 4.35 & 3.81 & 2 & 2 \\
\hline Histidine & 0.09 & 0.07 & 0.14 & 0.20 & 0.30 & 0.43 \\
\hline Arginine & 0.38 & 0.29 & 0.61 & 0.83 & 0.60 & 0.80 \\
\hline Threonine & 0.25 & 0.22 & 0.50 & 0.69 & 0.60 & 0.70 \\
\hline Valine & 0.41 & 0.36 & 0.60 & 0.83 & 0.70 & 0.85 \\
\hline $\begin{array}{l}\text { Methionine + } \\
\text { cystine }\end{array}$ & 0.05 & 0.05 & 0.18 & 0.24 & 0.60 & 0.60 \\
\hline Isoleucine & 0.38 & 0.30 & 0.46 & 0.63 & 0.60 & 0.70 \\
\hline Leucine & 0.62 & 0.50 & 0.91 & 1.24 & 1.10 & 1.25 \\
\hline $\begin{array}{l}\text { Phenylalanine + } \\
\text { tyrosine }\end{array}$ & 0.58 & 0.46 & 0.94 & 1.29 & 1.10 & 1.40 \\
\hline L.ysine & 0.49 & 0.41 & 0.83 & 1.10 & 0.65 & 0.90 \\
\hline EAAl & 43 & 36 & 74 & 102 & - & - \\
\hline $\mathrm{CBV}^{c}$ & 36 & 28 & 69 & 99 & 100 & 100 \\
\hline $\mathrm{CCS}^{a}$ & 92 & 92 & 70 & 60 & 0 & 0 \\
\hline
\end{tabular}

${ }^{\mathbf{a}}$ Requirements are based on the assumption that a high quality diet is fed (National Research Council 1977; Institute National de la Recherche Agronomique 1984).

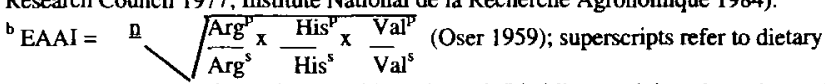

protein ( $p$ ) and growth requirement (s); and $n=9$ (histidine, arginine, threonine, valine, leucine, isoleucine, lysine, methionine + cystine, and phenylalanine + tyrosine were included in all computations).

${ }^{c}$ Computed biological value $=1.09$ (EAAI) -11.7 (Oser 1959)

"Coruputed chemical score $=$ the percent deficient of the most limiting essential amino acid for meeting growth requirements.

More frequent and dramatic temporal changes in diet quality may be associated with seasons (spring and fall) when many plants are actively growing or producing seed.

Summer diets dominated by warm-season grasses can present nutritional problems because grasses generally contain less high quality protein than forbs and decline in quality more rapidly with maturity than other forage classes (Bailey 1969, Bogle et al. 1989). Young cottontails show a distinct preference for higher quality forbs compared to grasses (Bailey and Siglin 1966). Bogle et al. (1989) found that digestibility remained high in forbs but not in grasses throughout summer. Nutritionally, rabbits are able to efficiently utilize protein in fibrous forages (Crampton and Forshaw 1940, Miller et al. 1954, National Research Council 1977, Schurg et al. 1977, Voris et al. 1940), but growth and survival are impaired when total nitrogen and digestibility are both low (Bailey 1969). Considering nutritional needs for growth and high preference for forbs, Chapman et al. (1982) postulated that an abundant source of amino acids, particularly sulfur-containing amino acids, is critical to juvenile survival. Although Bailey (1969) reported that cottontail survival on diets of warm-season grasses was poor, cool-season grasses in our study contained much higher quality proteins and were probably adequate for meeting maintenance requirements of adults in winter. The lower quality of proteins in mature summer forages compared to immature winter forages was the probable result of a dilutional effect from accumulated cell wall material such as lignin, cellulose, and hemicellulose (Lindroth et al. 1986).

Nonprotein $\mathrm{N}$ in many plants is a result of the plant storing $\mathrm{N}$ in the form of toxic metabolites for protection against herbivory; this $\mathrm{N}$ is redistributed as amino acids when required for growth (Mooney et al. 1983). Phenological changes in nonprotein $N$ concentrations were not apparent in 14 of 17 forages we examined. Exceptions included $P$. oligosanthes from undisturbed sites in summer, which increased nonprotein $\mathbf{N}$ concentrations with maturity, and $P$. oligosanthes from disturbed sites and Antennaria spp. from undisturbed sites in winter, which showed decreased content of nonprotein $\mathrm{N}$ with maturity. Decreases in the nonprotein $\mathrm{N}$ component in P. oligosanthes and Antennaria spp. corresponded with increases in the content of certain amino acids, especially lysine, supporting the suggestion of Mooney et al. (1983) that some forages may store $\mathrm{N}$ for later plant growth. Although rabbits are coprophagous, they are not similar to ruminants and cannot efficiently utilize nonprotein $\mathrm{N}$ in forages (Lebas 1988).

Another important nutritional consideration in the overall quality of proteins for growth and reproduction is diet digestibility. Snyder et al. (1976) estimated that cottontail rabbits require $1.92 \%$ digestible $\mathrm{N}$ (protein $=12 \%$ ) for growth. All forages in the summer diet of rabbits had both total $\mathrm{N}$ levels well below this level. In contrast, winter cool-season grasses contained total $\mathrm{N}$ levels at or above the growth requirement before correcting for digestibility. Digestibility of commonly fed forages in commercial rabbit operations average 64\% (National Research Council 1977). Dry matter digestibility of forages used by cottontails is extremely variable among seasons and specics (grasses $35-60 \%$, legumes $61-89 \%$, wild forbs $60-84 \%$; Bailey 1969), but is typically lowest in summer. Digestibility considerations indicate that summer forages and corresponding reconstructed diets were extremely deficient in all essential amino acids for all life processes. Although there is a paucity of digestibility information for winter forages used by rabbits, winter forages and diets were probably adequate with respect to most essential amino acids for maintenance and growth on disturbed habitats; exceptions included histidine and the sulfur-containing amino acids. Winter diets of rabbits from undisturbed habitats probably provided most essential amino acids for adult maintenance. Essential amino acid requirements for adult maintenance in the rabbit (cottontail or domestic rabbit) have not been published, but $\mathbf{N}$ requirements (corrected for protein digestibility) are $25 \%$ lower than those for growth (National Research Council 1977).

If amino acid requirements for domestic rabbits are an accurate representation of requirements for the cottontail rabbit, a paradoxical dilemma arises concerning how animals can reproduce and develop on natural forages of low biological value. Bailey (1969) clearly demonstrated the inability of young cottontails to survive on grass-dominated diets, especially in summer. Sinclair et al. (1982) proposed 3 alternative responses an individual may make to low diet quality: (1) maintain a constant rate of food intake by including more low quality forage; (2) increase the quantity eaten to compensate for the low quality of forage; or (3) selectively eat only high quality plants or plant parts, and decrease overall quantity eaten. The second option is widely thought to be a universal optimal foraging strategy of animals. However, a review of the literature on consumption rates in hares and rabbits suggests that intake of cottontail rabbits declines with declining protein quality of diets (Adamson and Fisher 1971, Bookhout 1965, Cheeke 1971, Gaman et al. 1970, McWard et al. 1967, Sinclair et al. 1982). Snowshoe hares studied by Sinclair et al. (1982) showed no consistent decline in rate of intake as total nitrogen levels declined, but no animal studied increased intake with declining total nitrogen content. 
Cottontail rabbits may adopt the first alternative above and maintain a constant consumption rate with seasonal declines in diet quality, and limit reproduction to seasons when adequate essential amino acid resources become available, as suggested by Ecke (1955). Reproductive status of adult rabbits harvested on our study area indicated that $41 \%$ of females ( 73 of 177 ) and $28 \%$ of males (40 of 144) were not reproductively active during July. Cottontail rabbits may compensate for periods of dietary protein deficiencies by storing protein in the form of muscle mass during periods of good nutrition and catabolizing protein reserves for critical amino acids during periods of nutritional stress. The evidence in support of such a strategy is limited; however, cottontail rabbit nutritional indices are known to peak one season prior to a period of nutritional stress (Chapman et al. 1977). Low maintenance requirements of adults permit them to endure periods of nutritional stress better than young, as indicated by greater juvenile mortality in lagomorphs when diet availability or quality is low (Gibb 1977). Under the first and third foraging strategies of Sinclair et al. (1982), the nutritional status of cottontail rabbits could be expected to decline, leading to reductions in physical condition and reproductive activity. The existence of chronic nutritional deficiencies on our study site was suggested by observed reductions in population densities in recent years (Lochmiller et al. 1991).

It remains likely that cottontail rabbits have the ability to forage more selectively than we could simulate via hand-collected plants, although, not to the extent necessary to compensate all essential amino acid deficiencies observed. Even though we exercised care in collecting and sorting (removal of dead stems and leaves) each forage sample for analysis, rabbits are thought to be efficient in selecting particularly nutritious plant parts (Chapman et al. 1982, Allen 1984). A second technical problem was that forages were hand-collected the year after they were identified as important food items in the diet. Diets consumed by cottontail rabbits probably change from year to year in response to availability and quality of vegetation (Chapman et al. 1982). Even with some technical error in sampling, it remains clear, given the magnitude of the differences in observed diet levels and published requirements for domestic rabbits, that certain essential amino acid limitations do exist in winter and summer forages from both disturbed and undisturbed habitats. Our data support the proposition of Chapman et al. (1982) that availability of sulfur-containing amino acids may be a critical determinant of juvenile survival and reinforces the need to consider the importance of protein quality in studies of nutritional factors regulating the dynamics of rabbit populations. The actual dietary requirements for growth and reproduction should now be determined for the first and second mostlimiting amino acids identified in this study to substantiate the comparability of domestic and cottontail rabbits.

\section{Literature Cited}

Adamson, I. and H. Fisher. 1971. The amino acid requirement of the growing rabbit: qualitative needs. Nutr. Rep. Internat. 4:59-64.

Allen, A.W. 1984. Habitat suitability index models: eastern cottontail. United States Fish and Wildlife Service, Fort Collins, Colo.

Anderson, B.F. and M.R. Pelton. 1976. Movements, home range, and cover use: factors affecting the susceptibility of cottontails to hunting. Proc. S.E. Assoc. Game and Fish Comm. 30:525-535.
Bailey, J.A. 1969. Exploratory study of nutrition of young cottontails. J. Wildl. Manage. 33:346-353.

Bailey, J.A. and R.J. Siglin. 1966. Some food preferences of young cottontails. J. Mammal. 47:129-130.

Bogle, L., D.M. Engle, and F.T. McCollum. 1989. Nutritive value of range plants in the cross timbers. Oklahoma Agr. Exp. Sta., Oklahoma State University, Stillwater, Okla. Rep. P-908.

Bookhout, T.A. 1965. The snowshoe hare in upper Michigan: its biology and feeding coactions with whitetailed deer. Michigan Dept. of Conserv., Lansing. Rep. No. 38.

Bothma, J.du P. and J.G. Teer. 1977. Reproduction and productivity in south Texas cottontail rabbits. Mammalia 41:251-281.

Chapman, J.A., A.L. Harman, and D.E. Samuel. 1977. Reproductive and physiological cycles in the cottontail complex in western Maryland and nearby West Virginia. Wildl. Monogr. 56:1-73.

Chapman, J.A., J.G. Hockman, and W.R. Edwards. 1982. Cottontails (Sylvilagus floridanus and allies), p. 83-123. In: J.A. Chapman and G.A. Feldhamer (eds) Wild mammals of North America: biology, management, and economics. The Johns Hopkins Univ. Press, Baltimore, Md

Cheeke, P.R. 1971. Arginine, lysine, and methionine needs of the growing rabbit. Nutr. Rep. Internat. 3:123-128.

Crampton, E.W. and R. Forshaw. 1940. Pasture studies XVI: the nutritive value of Kentucky blue grass, red top and brome grass. J. Nutr. 19:161-172.

Davitt, B.B. and J.R. Nelson. 1980. A method of preparing plant epidermal tissue for use in fecal analysis. Coll. of Agr. Research Center, Washington State Univ., Pullman, Wash. Circ. No. 0628.

Ecke, D.H. 1955. The reproductive cycle of the Mearns cottontail in Illinois. Amer. Midl. Natur. 53:294-311.

Engle, D.M., J.F. Stritzke, and F.T. McCollum. 1991. Vegetation management in the cross timbers: response of understory vegetation to herbicides and burning. Weed Tech. 5:406-410.

Ewing, A.L., J.F. Stritzke, and J.D. Kulbeth. 1984. Vegetation of the Cross Timbers Experimental Range, Payne County, Oklahoma. Oklahoma Agr. Exp. Sta., Oklahoma State Univ., Stillwater, Okla. Res. Rep. P-856.

Gaman, E., H. Fisher, and A.S. Feigenbaum. 1970. An adequate purified diet for rabbits of all ages. Nutr. Rep. Internat. 1:35-48.

Gehrke, C.W., L.L. Wall, J.R. Absheer, F.E. Kaiser, and R.W. Zumwalt. 1985. Sample preparation for chromatography of amino acids: acid hydrolysis of proteins. J. Assoc. Off. Anal. Chem. 68:811-821.

Gibb, J.A. 1977. Factors affecting population density in the wild rabbit, Oryctolagus cuniculus (L.), and their relevance to small mammals, p. 34-46. In: B. Stonehouse and C. Perrins (eds) Evolutionary ecology. Univ. Park Press, Baltimore, Md.

Holt, N.W. and F.W. Sosulski. 1981. Nonprotein nitrogen content of some grain legumes. Can. J. Plant Sci. 61:515-523.

Institute National de la Recherche Agronomique. 1984. L'alimentation des animaux monogastriques: porc, lapin, volailles. I.N.R.A., Paris, France.

Janes, D.W. 1959. Home range and movement of the eastern cottontail in Kansas. University of Kansas Publication, Museum of Natural History 10:553 -572.

Keith, L.B. 1983. Role of food in hare population cycles. Oikos 40:385-395.

Keith, L.B. 1987. Dynamics of snowshoe hare populations, p. 119-195. In: H.H. Genoways (ed.) Current mammalogy, Vol. 2. Plenum Press, New York, N.Y.

King, S.L., H.L. Stribling, and D. Speakes. 1991. Cottontail rabbit initial responses to prescribed burning and cover enchancement. J. Alabama Acad. Sci. 62:178-188.

Korschgen, L.J. 1980. Food and nutrition of cottontail rabbits in Missouri. Missouri Dep. of Conserv., Jefferson City, Mo. Terrestrial Ser. No. 6.

Krapu, G.L. and G.A. Swanson. 1975. Some nutritional aspects of reproduction in prairie nesting pintails. J. Wildl. Manage. 39:156-162.

Lebas, F. 1988. Rabbits. Livestock Prod. Sci. 19:289-298. 
Lindroth, R.L., G.O. Batzli, and D.S. Seigler. 1986. Patterns in the phytochemistry of three prairie plants. Biochem. System. Ecol. 14:597-602.

Lochmiller, R.L., J.F. Boggs, S.T. McMurry, D.M. Leslie, and D.M. Engle. 1991. Response of cottontail rabbit populations to herbicide and fire applications on cross timbers rangeland. J. Range Manage. 44:150-155.

Lochmiller, R.L., D.G. Peitz, S.T. McMurry, D.M. Leslie, and D.M. Engle. 1995. Alterations in condition of cottontail rabbits (Sylvilagus floridanus) on rangelands following brush management. J. Range Manage. 48:232-239.

Maynard, L.A., J.K. Loosli, H.F. Hintz, and R.G. Warner. 1979. Animal nutrition. McGraw-Hill Publications, New York, N.Y.

McMurry, S.T., R.L. Lochmiller, J.F. Boggs, D.M. Leslie, and D.M. Engle. 1993. Opportunistic foraging of eastern woodrats (Neotoma floridana) in manipulated habitats. Amer. Midl. Natur. 130:325-337.

McWard, G.W., L.B. Nicholson, and B.R. Poulton. 1967. Arginine requirement of the young rabbit. J. Nutr. 92:118-120.

Miller, W.J., R.K. Waugh, and G. Martrone. 1954. Comparison of digestibility of certain pasture forages in the fresh and dried states. J. Anim. Sci. 13:283-288.

Mitchell, H.H. and R.J. Block. 1946. Some relationships between the amino acid contents of protein and their nutritive value for the rat. $J$. Biol. Chem. 163:599-620.

Mooney, H.A., S.L. Gulman, and N.D. Johnson. 1983. Physiological constraints on plant chemical defenses, p. 21-36. In: A. Hedin (ed) Plant resistance to insects. Amer. Chem. Soc., Washington, D.C.

Murphy, M.E. and S.D. Pearcy. 1993. Dietary amino acid complementation as a foraging strategy for wild birds. Physiol. Behav. 53:689-698.

National Research Council. 1977. Nutrient requirements of rabbits. Natl. Acad. Sci., Washington, D.C.

Oftedal, O.T. 1991. The nutritional consequences of foraging in primates: the relationship of nutrient intakes to nutrient requirements. Philosoph. Trans. Royal Soc. London, B 334:161-170.

Oka, T.O. and K. Sasaoka. 1985. Free amino acids and related compounds in seeds and sprouts of winged bean (Psophocarpus tetragonolobus L.). J. Food Sci. 50:1503-1504.

Oser, B.L. 1959. An integrated essential amino acid index for predicting the biological value of proteins, p.281-295. In: A.A. Albanese (ed) Protein and amino acid nutrition. Academic Press, Inc., New York, N.Y.

Pease, J.L., R.H. Vowles, and L.B. Keith. 1979. Interaction of snowshoe hares and woody vegetation. J. Wildl. Manage. 43:43-60.

Pelton, M.R. and E.E. Provost. 1972. Onset of breeding and breeding synchrony by Georgia cottontails. J. Wildl. Manage. 36:544-549.

Peoples, A.D., R.L. Lochmiller, D.M. Leslie, J.C. Boren, and D.M. Engle. 1994. Essential amino acids in northern bobwhite foods. J. Wildl. Manage. 58:167-175.

Rogowitz, G.L. 1992. Reproduction of white-tailed jackrabbits on semiarid range. J. Wildl. Manage. 56:676-684.

Sarwar, G., D.A. Christensen, A.J. Finlayson, M. Friedman, L.R. Hackler, S.L. Mackenzie, P.L. Pellett, and R. Tkachuk. 1983. Interand intra-laboratory variation in amino acid analysis of food proteins. J. Food Sci. 48:526-531.

SAS. 1988. SAS/STAT User's Guide (Release 6.03). SAS Inst., Inc., Cary, N.C.

Schurg, W.A., D.L. Frei, P.R. Cheeke, and D.W. Holtan.1977. Utilization of whole corn plant pellets by horses and rabbits. J. Anim. Sci. 45:1317-1321.

Sedinger, J.S. 1984. Protein and amino acid composition of tundra vegetation in relation to nutritional requirements of geese. J. Wildl. Manage. 48:1128-1136.

Sinclair, A.R.E., C.J. Krebs, and J.N.M. Smith. 1982. Diet quality and food limitation in herbivores: the case of the snowshoe hare. Can. J. Zool. 60:889-897.

Singh, U. and R. Jambunathan. 1981. Relationship between nonprotein nitrogen and total nitrogen in chickpea (Cicer arietinum L.) seed. J. Agr. Food Chem. 29:423-424.

Smith, R.H. 1980. Comparative amino acid requirements. Proc. Nutr. Soc. 39:71-78.
Snyder, W.I., M.E. Richmond, and W.G. Pond. 1976. Protein nutrition of juvenile cottontails. J. Wildl. Manage. 40:484 490.

Soper, R.B., R.L. Lochmiller, D.M. Leslie, and D.M. Engle. 1993. Nutritional quality of browse after brush management on cross timbers rangeland. J. Range Manage. 46:399-410.

Steen, J.B., O. Andersen, A. Saebo, H.C. Pedersen, and K.E. Erikstad. 1988. Viability of newly hatched chicks of Willow Ptarmigan (Lagopus l. lagopus). Ornis Scand. 19:93-96.

Stritzke, J.F., D.M. Engle, and F.T. McCollum. 1991. Vegetation management in the cross timbers: response of woody species to herbicides and burning. Weed Tech. 5:400-405.

Thomas, V.G. and J.P. Prevett. 1980. The nutritional value of arrowgrasses to geese at James Bay. J. Wildl. Manage. 44:830-836.

Trent, T.T. and O.J. Rongstad. 1974. Home range and survival of cottontail rabbits in southwestern Wisconsin. J. Wildl. Manage. 38:459-472.

Trethewey, D.E.C. and B.J. Verts. 1971. Reproduction in eastern cottontail rabbits in western Oregon. Amer. Midl. Natur. 86:463-476.

Turkowski, F.J. 1975. Dietary adaptability of the desert cottontail. J. Wildl. Manage. 39:748-756.

Vaughan, M. and L.B. Keith. 1981. Demographic response of experimental snowshoe hare populations to overwinter fond shortage. J. Wildl. Manage. 45:354-380.

Voris, L., L.F. Marcy, E.J. Thacker, and W.W. Wainio. 1940. Digestible nutrients of feeding stuffs for the domestic rabbit. J. Agr. Res. 61:673-683.

White, T.C.R. 1978. The importance of a relative shortage of food in animal ecology. Oecologia 33:71-86.

Williams, S. 1984. Official methods of analysis of the association of official analytical chemists, fourteenth edition. Assoc. Off. Anal. Chem., Washington, D.C.

Zinn, R.A. and F.N. Owen. 1993. Ruminal escape protein for lightweight feedlot calves. J. Anim. Sci. 71:1677-1687. 